\title{
Influence of Teachers Qualification on Quality of Teaching Mathematics in Public Secondary Schools in Kisumu County, Kenya
}

\author{
Manoah Sylvia Awuor
}

\begin{abstract}
Teachers of Mathematics in Kenya have attended in-service program for the purpose of enhancing their skills and improving quality of teaching. However, this has not been translated into improved performance as expected. There has been persistent low performance in Mathematics in secondary schools in general for the period 2012-2019 during which the mean score dropped from $20.12 \%$ to $19.86 \%$ nationally. The trend of low mean score has been identified in secondary schools in Kisumu County which dropped from $34.00 \%$ to $20.45 \%$ for the same years. The purpose of this study was to establish influence of teachers' qualification on quality of teaching Mathematics. Objectives of the study were to: establish teachers' qualification; establish teachers' quality of teaching mathematics and to determine influence of teachers' qualification on quality of teaching mathematics. The study was anchored on Educational Production Function Theory by Bowles (1970) model. Descriptive survey design was employed in which the dependent variable was quality of teaching mathematics and independent variable was teachers' qualification. The target population was 234 teachers and 7 SQASO. The sample size was 70 teachers and 6 SQASO. Research instruments were Lesson Observation Guide (LOG) and SQASO Interview Guide. A pilot study was carried using test- retest method and the reliability coefficient for LOG was 0.78 and SIG 0.82. Quantitative data was analyzed using descriptive statistics which involved arithmetic mean, standard deviation, frequencies and percentages. Inferential statistics involved Analysis of Variance (ANOVA). Qualitative data was analyzed by organizing responses from questionnaire and reported as verbatim excerpts. Findings revealed that teachers' qualification had significant differences with Master's holders performing best $(M=67.25 ; \mathrm{SD}=6.36)$. The findings may be useful to policy makers, teachers, school principals and SQASO on how qualification influences quality of teaching Mathematics in secondary schools. It is recommended that teachers with qualification of Masters in Mathematics Education to be appointed INSET trainers.
\end{abstract}

Index Terms - Mathematics teachers' qualification, quality of teaching mathematics, secondary schools.

\section{INTRODUCTION}

The global community's commitment over quality in education at basic level of education has been emphasized in many international forums including the world conference on Education For All, adopted in Jomtein, Thailand in 1990. Mathematics education is a global challenge that needs urgent local solutions [30]. Research has shown that successful professional development experiences have a noticeable impact on teachers work in and out of the classroom [32]. Reference [7] asserts that in order to provide quality experiences for all learners, lessons must be planned and prepared properly for quality teaching and learning. Reference [17] supports Armstrong's view on teachers' preparation as being vital for quality teaching and learning progress. Reference [13] noted that the best way one can show that quality of education is being provided and teachers are effective is by the number of students who qualify for university education. For many decades, studies have been conducted to investigate the teaching and learning of Mathematics [9]. A growing body of research shows that differences in students' achievement is attributed to teachers' and their teaching methods [18]. Availability of qualified teachers determines the performance of students in schools [4]. In contrast a study done by[21] reveals that there is no difference in performance between teachers who have degree or diploma suggesting that teacher professional qualification does not result to increased students' academic achievement. Similarly, [20] is in support [21] findings hence concluded that teachers' age, gender, both professional qualification and experience did not have significant effect on academic achievement in secondary schools in Nyandarua County. One way of improving the quality of education is through quality of teaching. Examining the quality of teaching will improve understanding of what happens in the classrooms that may explain differences in performance among schools. Understanding what quality mathematics pedagogy looks like has not been finalized [33]. Teachers' mathematical knowledge can better be assessed when they are observed in class.

Influence of Teachers' Qualification on quality of teaching mathematics

A well-qualified teacher is one who was fully certified and holds the equivalent of a major in the field being taught [9]. The issue of teacher as a factor that affect students' performance has received a lot of attention of late and findings have been mixed and inconclusive. Related literature reveal that a number of teacher variables including teacher qualification affect students learning outcomes [3], [4], [5], [11]. Although the formal qualification of teachers is an important indicator for their knowledge and competence in teaching, it has limited utility in analyzing how well prepared teachers are for what they have to teach in classrooms. Availability of qualified teachers determines students' 
performance in schools [4]. Reference [19], examined whether years of teaching experience or academic qualification has an effect on overall achievement of students communication arts and mathematics. The study used descriptive statistics and factorial ANOVA. Results indicated that teacher degree level alone had no effect on students' achievement.

Reference [24] conducted a research on factors contributing to under achievement in Zambian female students in O Level Physics examinations which found that lack of qualified teachers of Physics had a significant contribution. A related study was done in Nigeria by [2] who found that lack of qualified teachers' contributed to consistent poor performance of students in subjects like science, mathematics and technology. Links between students' achievement and teachers' qualification has been established [14]. Data on post-secondary degree and certification status of teachers and their students' performance in mathematics and science was examined [14], the results showed a positive relationship between degrees and students performance in mathematics. Reference [16] analysed results of 113 studies on the impact of teachers' qualification on students' academic achievement. Results showed that eighty five percent of the studies had no positive correlation between educational performance of the students and teachers' educational background. Although seven percent of the studies found a positive correlation, five percent found a negative impact. Reference [28] examined the effects of teachers' qualifications on performance in mathematics among secondary school students in Kaduna state. Purposive sampling was used to select 12 senior secondary schools from four inspectorate divisions in the state who participated in the study. In the second stage a random sample of 160 further mathematics students were finally selected across the four divisions. Two instruments were used ;Teacher Self-Assessment Test with reliability index of 0.87 and a 30 -item four option multiple choice further Mathematics Achievement Test was constructed by the researchers with Cronbach's alpha of 0.87 and a difficulty of item at $(.40<p<.82)$ were administered. Two research questions and one hypothesis was formulated to guide the study. The Analysis of Variance revealed that significant difference existed between students' performance on account of their teachers' qualifications.

Reference [27] studied the relationship between teachers' qualification and students' performance in mathematics, in Ikpoba-Okha L.G.A, Edo State. The study was a Correlation survey and was conducted using 25 private secondary schools randomly selected and a sample size of 50 mathematics teachers purposively selected from the area of study. The study was guided by four research questions and four null hypotheses. The instrument used for data collection was the Teachers' Qualification and Students' Mathematics Achievement Questionnaire (TQSMAQ) which was developed by the researchers. The instrument was validated and had a reliability coefficient of .983 using the rho statistics One of the findings of the study showed that the relationship between mathematics teachers' qualification and percentage of passes among students' in mathematics has a negative partial correlation of 0.245 which was less than the significance level 0.176 . One of the study's conclusions was that the quality of mathematics teachers engaged by schools would either positively or negatively impact the performance of students in the subject. However, unlike in the research done by [27] where the researchers used correlation design, the current study used descriptive design; private schools were used as study population in the former study whereas the current study used public secondary schools; the tool used in collecting data in the former study was TQSMAQ questionnaire while the tools used in the current study were Lesson Observation Guide (LOG) and SQASO Interview Guide in order to enrich the research findings..

A study by [25] looked into the extent to which teacher qualification influenced students' academic performance in Science, Mathematics and Technology (SMT) subjects. The study applied ex-post-facto survey research design while random sampling was used to select eight secondary schools in Kitui County. The sample size included 8 head teachers, 40 teachers of SMT subjects and 600 candidates who sat for the Kenya Certificate of Secondary Education in the year 2012. Data was collected using questionnaire and document analysis. It was analyzed using descriptive and inferential statistical tools. The study found that there was no significant difference in means between teacher qualification and students' performance in SMT subjects at form four level. The findings of the study further revealed that majority of the teachers of SMT subjects were trained graduates, most of them had attended in-service or refresher courses which resulted in slight improvement in the students' performance in SMT subjects. The current study established teachers qualification in terms of their quality of teaching mathematics in classrooms after attending in service course.

Reference [1] examined the effect of teachers' qualification on students' performance in mathematics whose results showed that a significant difference existed in the students taught by professional teachers and non-professional teachers. The researcher's suggestion was that teachers with certificate in education should be allowed to proceed with their education either through part time or study leaves likewise teachers without qualification should be advised to pursue their Post Graduate Diploma in Education. Some studies found that teachers' experience and educational qualifications significantly influenced students' academic achievement [28], [8], [6]. So far studies done show that researchers have never reached a consensus on specific teacher background which influence students' academic achievement.

Reference[12] study focused on comparing mathematics teachers on qualification, practices and perception between Saudi and Taiwanese schools. Analysis of data in this study were responses of Mathematics teacher on the Teacher Background Questionnaire-8th Grade from Trends in International Mathematics and Science Study (TIMSS) in 
2007. The Saudi sample consisted of 171 teachers while the Taiwanese sample consisted of 152 teachers. The comparison between the two countries revealed that some teachers' qualification and practices were related to students' scores. While [12] study focused on two countries, the present study focused on a county within Kenya which has 47 counties in total, again the former study focused on a total of 323 teachers from the two countries, the current study used 70 mathematics in-service trained teachers who were teaching in sub- county secondary schools.

The issue of teacher as a factor that affect students' performance has received a lot of attention and findings have been mixed and inconclusive. Some studies among others reveal that teacher qualification affect students learning outcome[5], [11]. Some studies found that teachers' qualification alone had no effect on students' achievement [19]. Some studies found no significance difference in means between teacher qualification and students performance [25]. Some studies examined the effect between teachers qualification on students' performance in mathematics and results showed that significance difference existed between students taught by professional teachers and non-professional teachers [1]. None of the studies reviewed looked at teachers' qualification in relation to their quality of teaching mathematic. Given the above literature there was need to establish influence of teachers qualification on quality of teaching mathematics in secondary schools by observing them in class as they handled different topics .

\section{Specific objectives of the study were to:}

1. Establish teachers' qualification.

2. Establish teachers' quality of teaching.

3. Determine influence of teachers' qualification on quality of teaching mathematics.

\section{Research Hypothesis}

1. Teachers' qualification has no significant difference on quality of teaching mathematics.

\section{RESEARCH METHODOLOGY}

\section{Venue and sample}

The study was carried out in Kisumu County in Kenya. It lies within longitudes $34^{\circ} 20^{\prime} \mathrm{E}$ and $35^{\circ} 20^{\prime} \mathrm{E}$ and latitudes $0^{\circ}$ $20^{\prime} \mathrm{S}$ and $0^{\circ} 50^{\prime} \mathrm{S}$. The County has a shoreline on Lake Victoria, which is the second largest fresh water lake in the world, occupying northern, western and a part of the southern shores of Winam Gulf. The study used $30 \%$ of the target population (234) of in service trained teachers which produced a sample of 70 in-service trained teachers who used students whom they teach regularly in various classes and are found in sub county public secondary schools.

\section{Data collection instruments}

Two tools were used. These were Lesson Observation Guide (LOG) and Sub-county Quality Assurance and Standards Officers Interview Guide (SIG). For the study to yield meaningful data, LOG which had a graphic rating scale was developed for the purpose of rating teachers' quality of teaching mathematics. Kothari (2004) states that the rating scale is preferable in doing a classroom observation because it enables a researcher to get systematic and uniform information during the study. The researcher used LOG as a tool to help establish mathematics teachers' quality of teaching and it also provided information on teachers' background and allowed the researcher to see what actually teachers do in classrooms. SQASO interview guide was used to get information on teachers' quality of teaching mathematics as they observe teachers in class during curriculum implementation.

\section{Validity and Reliability of the instruments}

The face and content validity of LOG, and SIG were presented to experts in the field of education [25]. Content validity of the instruments were then established after two experts had evaluated the relevance of each item in the instruments to the objectives. To do this, the experts rated each item on the scale: very relevant (4), quiet relevant (3), somewhat relevant (2), and not relevant (1). Validity was determined using Content Validity Index (C.V.I).The C.V.I = Items rated 3 or 4 by both experts divided by the number of items in the research instruments. The reliability of LOG and SIG was established through test retest method as proposed by [22] and application of Pearson Product Moment Correlation. To do this a pilot study was conducted using 16 teachers (not part of the sample size), representing $10 \%$ of the total number of In- service trained teachers found within sub county schools and 1 SQASO all within Kisumu County [23].The same instruments were administered twice to the same respondents within an interval of two weeks. Applying SPSS version 21, the scores were correlated using Pearson Product Moment Correlation Coefficient. The instruments were accepted as reliable when each instrument yielded a Correlation Coefficient of 0.78 and 0.82 respectively [25].

\section{Data Collection Procedure}

A research authorization letter was obtained from School of Graduate Studies (SGS), Maseno University before embarking on the study. After which the proposal was presented to Maseno University Ethics Review Committee (MUERC) for approval. On obtaining a letter of approval from (MUERC), the researcher sought for a research permit from the National Commission of Science, Technology and Innovation (NACOSTI). The researcher presented the permit from NACOSTI to the County Director of Education Kisumu, who then wrote a letter concerning the research to be done in the county. The researcher then availed copies of the letter from the County Director of Education in Kisumu which was presented to each of the 7 Sub-County Directors of Education in charge of the 7 sub-counties. The instruments were administered through personal visits on appointment with mathematics teachers through school principals. The researcher observed teachers in class using the LOG as was agreed upon on different days. SQASO were interviewed at their stations of work. The information given by all the respondents in this study was used for data analysis. 


\section{Data Analysis Procedure}

The data from LOG provided information on teacher qualification. Teacher qualification was given dummy figures during analysis depending on the category. Diploma in Education-1, B.Ed/PGDE-2, Masters in Mathematics Education-3, and PhD in Mathematics Education-4.The LOG provided the scores teachers obtained during lesson observation. During data analysis on teachers' quality of teaching mathematics, percentage score for individual teacher was done depending on the scores assigned for each construct to be measured from the LOG. Quantitative data analysis involved the use of descriptive statistics which involved arithmetic mean, standard deviation,

frequencies and percentages while inferential statistics involved use of ANOVA (one-tail) to determine relationship between teacher qualification and quality of teaching mathematics. Qualitative data was analysed using interview with SQASO which was transcribed and organized in categories and reported as verbatim excerpts.

\section{RESULTS AND DISCUSSION}

The study established teachers' professional qualification in the teaching of mathematics in secondary schools in Kisumu County by using Lesson Observation Guide (LOG) attached as Appendix I which was used by the researcher during lesson observation in classrooms. Table 3 indicates that majority of the teachers $56(80 \%)$ who were observed in class had B.Ed./PGDE degree out of a total number of 70 teachers. Very few teachers $6(8.57 \%)$ were Diploma holders and $8(11.43 \%)$ were Masters holders in mathematics education. None of the teachers had PhD in mathematics.

Table 1: Distribution of Teachers Qualification

\begin{tabular}{lcc}
\hline Qualification & Frequency & Percentage \\
\hline Diploma & 6 & 8.57 \\
B. Ed. /PGDE & 56 & 80.00 \\
Masters in M. Education & 8 & 11.43
\end{tabular}

\section{Quality of Teaching Mathematics in secondary schools}

Data regarding quality teaching of mathematics (QTM) was obtained from Lesson Observation Guide (LOG), which was attached as Appendix I. The result was reported in form of percentage scores for individual teacher depending on the score given to each construct in the LOG as they were teaching different topics in mathematics at different levels of classes in secondary schools. The distribution of scores obtained as percentage by individual teachers to show their quality of teaching mathematics was presented in Fig 1.

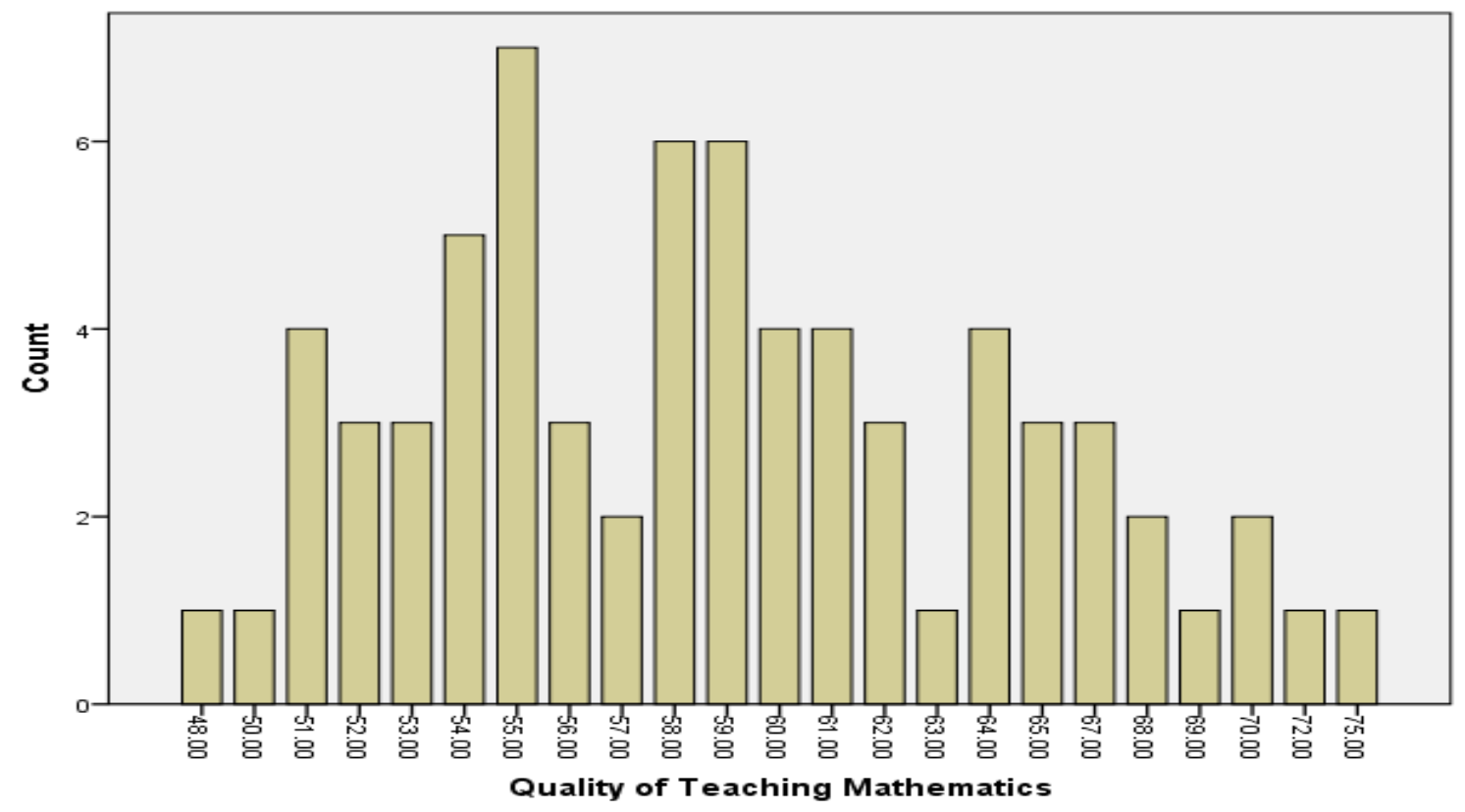

Fig 1: Teachers scores on Quality of Teaching Mathematics

Results from Fig 1 indicate that 1(1.4\%) teacher scored $48 \%$ which was the lowest score. The highest score was $75 \%$ which was also attained by $1(1.4 \%)$ teacher. The second highest score was $72 \%$ which came from $1(1.4 \%)$ teacher. Those who scored between $50 \%$ and $59 \%$ were $41(58.6 \%)$ teachers. Those who scored between $60 \%$ and $69 \%$ were $25(35.7 \%)$ teachers while those who scored between $70 \%$ and above were $4(5.7 \%)$ teachers. When individual teacher's quality teaching of mathematics was rated it was established that only $4(5.7 \%)$ teachers showed a very high quality of teaching mathematics, 21(30\%) teachers were rated as having high quality of teaching, $44(62.9 \%)$ showed average quality of teachings while only $1(1.4 \%)$ teacher was rated as having low quality of teaching mathematics. This is shown in Table II. 
Table II: Summary of scores obtained by teachers during lesson observation

\begin{tabular}{llll}
\hline Score & No. of teachers & Percentage & Rating \\
\hline 70 and above & 4 & 5.7 & Very High Quality \\
$60-69$ & 25 & 35.7 & High Quality \\
$50-59$ & 40 & 57.2 & Average \\
$40-49$ & 1 & 1.4 & Low Quality \\
$0-39$ & 0 & 0.0 & Very low Quality \\
\hline
\end{tabular}

\section{Source of Rating scale: University of Nairobi}

As shown in Table II, majority of teachers 40((57.2S \%) are the ones who were rated as having average quality of teaching mathematics. Only $4(5.7 \%)$ teachers are those who were rated as having very high quality of teaching mathematics. Only one teacher was rated as having low

Table III: Results of Quality of Teaching Mathematics as provided by descriptive statistics n =70

\begin{tabular}{llll}
\hline Min & Max & Mean & SD \\
\hline 48 & 75 & 59.04 & 5.877 \\
\hline
\end{tabular}

$\mathrm{SD}=$ Standard Deviation

The mean of 59.04 is an output which shows the input teachers showed during lesson observation as

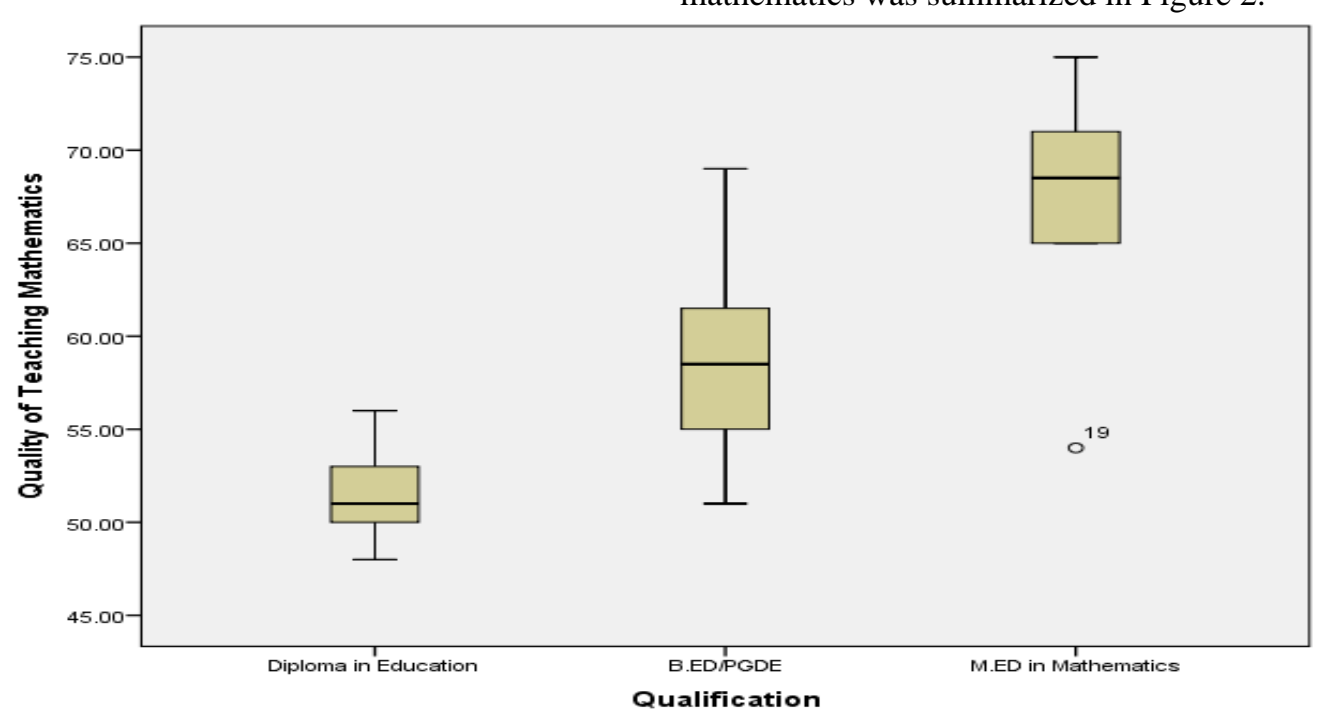

Fig 2: Teacher qualification on quality of teaching mathematics

Observing Fig 2 and referring to the boxplot for diploma teachers, the boxplot is moderately symmetrical as the box is almost in the middle of the whiskers and the median is only slightly below the middle of the box. This suggests that this data is very slightly negatively skewed. On average diploma teachers performed at a mean of 51.5. Considering this mean, it implies that diploma teachers can as well teach mathematics and help students perform well in mathematics.

The boxplot for B.ED/PGDE is symmetrical. This means that teachers in this category had their performance normally distributed without outliers. On average the teachers' performance in quality of teaching mathematics was at a mean of 58.7. The boxplot for teachers with Master's degree quality of teaching. When descriptive statistics for the 70 teachers was worked out, it produced a minimum score of $48 \%$ and a maximum score of $75 \%$ with a mean of 59.04 and a standard deviation of 5.877 as shown in Table III. they were teaching mathematics in the various classes. The results for teacher qualification on quality of teaching mathematics was summarized in Figure 2.

was almost symmetrical with one outlier who is teacher number 19. This teacher had the lowest performance in quality of teaching mathematics within this category which was confirmed as 54\% from Appendix IV. The performance of teachers in this category on quality of teaching mathematics was 67.25.

Relationship between teachers' qualification and Quality of Teaching Mathematics

Before establishing influence of teachers' qualification on quality of teaching mathematics, the mean scores on level of quality of teaching mathematics for the three categories of qualification of teachers was established using descriptive statistics and the results are presented in Table 4. 
Influence of Teachers Qualification on Quality of Teaching Mathematics in Public Secondary Schools in Kisumu County, Kenya

Table IV: Descriptive Statistics on level of quality of teaching mathematics given teachers' qualification $(n=70)$

\begin{tabular}{|c|c|c|c|c|c|c|}
\hline \multirow[t]{3}{*}{ Qualification } & \multirow[t]{3}{*}{$N$} & \multirow[t]{3}{*}{ Mean } & \multirow[t]{3}{*}{$\begin{array}{c}\text { Std. } \\
\text { Deviation }\end{array}$} & \multirow[t]{3}{*}{ Std. Error } & \multicolumn{2}{|c|}{$\begin{array}{c}\text { 95\% Confidence Interval for } \\
\text { Mean }\end{array}$} \\
\hline & & & & & Lower & Upper Bound \\
\hline & & & & & Bound & \\
\hline Diploma in Education & 6 & 51.5000 & 2.73861 & 1.11803 & 48.6260 & 54.3740 \\
\hline B.ED/PGDE & 56 & 58.6786 & 4.62054 & .61745 & 57.4412 & 59.9160 \\
\hline M.ED in Mathematics & 8 & 67.2500 & 6.36396 & 2.25000 & 61.9296 & 72.5704 \\
\hline Total & 70 & 59.0429 & 5.87659 & .70239 & 57.6416 & 60.4441 \\
\hline
\end{tabular}

From Table IV, it is evident that the difference in mean scores contrasts with that of [27] who found a negative partial of quality of teaching mathematics between the different categories of qualification of teachers was relatively large ranging from 51.5 to 67.3. Teachers who had Diploma in Education had the least mean score of quality of teaching mathematics $(M=51.5 ; S D=2.7)$, while those with $\mathrm{M}$. in Mathematics Education had the highest mean score in quality of teaching mathematics $(M=67.3 ; S D=6.4)$.

The finding is in line with [14] who examined the effect of teachers' certification status and their students' performance in mathematics and science in secondary schools whose results showed a positive relationship between degrees and students' performance in mathematics. The above finding

correlation of 0.245 on relationship between mathematics teachers qualification and percentage of passes among students in mathematics. The study concluded by noting that the quality of mathematics teachers engaged by schools would either positively or negatively impact the performance of students in mathematics.

\section{ANOVA showing statistical differences in quality of teaching mathematic given different categories of qualification}

For ANOVA to be run, a test on homogeneity of variances was first checked to establish the appropriateness of the teachers' qualification data for the use of ANOVA test. The test of homogeneity of variances indicates that the data met the required assumption for the test as shown in Table V.

Table V : Test of Homogeneity of Variances on Quality of Teaching Mathematics

\begin{tabular}{cccc}
\hline Levene Statistic & df1 & df2 & Sig. \\
\hline 1.395 & 2 & 67 & 0.255
\end{tabular}

The Levene test for homogeneity of variances, which tests whether the variance in scores is the same for each of the three groups, was not significant (Sig. value $=0.255)$. This suggests that the assumption of homogeneity of variance was not violated. It was therefore assumed that variances were equal across groups of different qualifications, an indication that the data was suitable for use of ANOVA. The Levene's result was sufficient for ANOVA to be used, therefore a model in the form $\bar{x}_{1} \neq \bar{x}_{2} \neq \bar{x}_{3}$ was necessary where $\bar{x}_{1=51.5,} \bar{x}_{2}=58.7$ and $\bar{x}_{3}=67.3$. ANOVA was then computed to establish whether there was any statistically significant difference in quality of teaching mathematics

Table VI: ANOVA; Level of quality of teaching mathematics given teachers' qualification

\begin{tabular}{lccccc}
\hline & Sum of Squares & df & Mean Square & F & Sig. \\
\hline Between Groups & 887.657 & 2 & 443.829 & 19.888 & .000 \\
Within Groups & & & & \\
Total & 1495.214 & 67 & 22.317 & & \\
\hline
\end{tabular}

From Table VI, it is evident that there was a statistically significant difference in the level of quality of teaching mathematics among the three different levels of given different categories of qualification among public secondary school teachers. In the ANOVA, dependent variable for the study was quality of teaching mathematics, measured in continuous scale, while the independent variable was teachers' qualification which was measured in categorical scale. Teachers' qualification was divided into three categories (category 1: Diploma in Education; category 2: B.ED/PGDE and category 3: M.ED in Mathematics).

ANOVA test was run to show the level of quality of teaching mathematics within the various teachers' qualifications as shown in Table VI.

qualifications among public secondary school teachers [F (2, $67)=19.888, p=.000<.05]$. The fairly large $F$ ratio shown in the results confirm that there was higher variability between 
the teachers' qualification categories caused by the independent variable than there was within each teachers' qualification category (error term). A significant $\mathrm{F}$ value suggests that there was sufficient evidence to reject the null hypothesis, which assumed that the population means were equal. On the other hand, the effect size, was calculated using eta squared which indicate that the differences were fairly small. The eta squared value being .373, which in Cohen and Cohen's (1988) terms was considered a small effect size. The general interpretation of effect size was as follows: small $(\mathrm{d}=$ $0.2)$, medium $(\mathrm{d}=0.5)$, and large $(\mathrm{d}=0.8)$ based on benchmarks suggested by Cohen (1988).

ANOVA test established that there was a significant difference in level of quality of teaching mathematics among the various level of qualification groups, the test did not show which of the groups differed significantly in quality of teaching mathematics. Thus, post-hoc test analysis was further performed to establish the groups that differed significantly, as shown in multiple comparisons results in Table VII.

Table VII: Multiple Comparisons: Level of quality of teaching mathematics given teachers' qualification (N=70)

Dependent Variable: Quality of Teaching Mathematics
(I)
Qualification
(J) Qualification
Mean
Difference (I-J) Error
Std.

\section{Sig. $\quad 95 \%$ Confidence Interval} Lower Upper Bound Bound

\begin{tabular}{|c|c|c|c|c|c|c|c|c|}
\hline & & & & & & & Bound & Bound \\
\hline & & & B.ED/PGDE & $-7.17857^{*}$ & 2.02927 & .002 & -12.042 & -2.3146 \\
\hline & Diploma & in & D.ED/FUDE & & & & 5 & \\
\hline & Education & & M.ED in Mathematics & $-15.75000^{*}$ & 2.55128 & .000 & -21.865 & -9.6349 \\
\hline Tukey & & & Diploma in Education & $7.17857^{*}$ & 2.02927 & .002 & 2.3146 & 12.0425 \\
\hline HSD & B.ED/PGDE & & $M F D$ in Mathematics & $-8.57143^{*}$ & 1.78552 & .000 & -12.851 & -4.2917 \\
\hline & & & VI.ED in Mratmematics & & & & 1 & \\
\hline & M.ED & in & Diploma in Education & $15.75000^{*}$ & 2.55128 & .000 & 9.6349 & 21.8651 \\
\hline & Mathematics & & B.ED/PGDE & $8.57143^{*}$ & 1.78552 & .000 & 4.2917 & 12.8511 \\
\hline
\end{tabular}

$*$. The mean difference is significant at the 0.05 level.

From Table VII, Turkey HSD post-hoc test which is a stepwise multiple comparison procedure was used to identify scores of quality of teaching mathematics that were significantly different from each other given the differences in teacher qualification. This test is often used whenever a significant difference between two or more sample means has been detected by ANOVA. The post-hoc test results showed that the level of quality of teaching mathematics significantly differed among the categories. In particular, teachers with a qualification of Masters in Mathematics Education's quality of teaching mathematics was significantly different (Sig. level <.05) from those teachers with qualification of Diploma in Education [Mean Difference $=15.75 ; S E=2.55$ ] and also those teachers with qualification of B.ED/PGDE [Mean Difference $=8.57 ; S E=1.79]$. Equally, there was a statistical significant difference in the level of quality of teaching mathematics between the group of teachers with qualification of Diploma in Education and those with qualification of B.ED/PGDE [Mean Difference=7.17; $S E=2.03 ; \quad p=.002$ ]. The finding is in line with Umar et al. (2013) study who found significant difference which existed between students' performance on account of their teachers qualification. Similarly, [1] examined the effect of teachers' qualification on students' performance in mathematics and also found significant difference which existed between students who were taught by professional teachers and non-professional teachers. In contrast, [25] found that there was no significant difference in means between teacher qualification and students' performance in science, mathematics and technology. Based on the results, teachers' qualification has a significant influence on quality of teaching mathematics among secondary school mathematic teachers, with higher qualification resulting into higher quality of teaching mathematics than those with a lower qualification.

Sub-County Quality Assurance and Standard Officers (SQASO) were interviewed to find their opinion on whether teachers' qualification contribute to quality teaching of mathematics. The following statements were noted:

"Yes, it is grounded on the level of education especially when genuine character is expressed and applied". SQASO 1.

"Yes, understanding of concepts depends on academic level”. SQASO 6

These excerpts imply that teachers' qualification may contribute to quality of teaching mathematics hence students' performance in mathematics. The findings contrast with those studies done by [15], [20], [24] who found that teacher qualification and experience were not significantly related to students achievement. In other words, even if teachers are more qualified this may not contribute to students' achievement at KCSE. There may be other factors such as students' attitude, students' background and also school factors which may intervene hence interfere with students' achievement. References [34], [15] found that postgraduate qualification at Master or higher level were not significantly related to students' achievement. However, most of the previous studies looked at teacher qualification in terms of 
students' achievement in mathematics. The results of the current study was to establish influence of teachers' qualification on quality of teaching mathematics which was established by analysis of variance.

\section{IMPLICATION}

The variation notwithstanding; teachers' quality of teaching mathematics in Kisumu County at a mean percentage of 59.04 is considered as average performance. This result can be used to improve students' performance in mathematics. If teachers can implement the in service activities they engage in during the training and help learners change their attitude towards mathematics this can help improve mathematics performance at secondary schools.

\section{RECOMMENDATION}

Based on the above conclusion, the study recommends that teachers holding Master degree in mathematics Education to be appointed as INSET trainers by Centre of Mathematics, Science, Technology Education in Africa (CEMASTEA) to enable them use their knowledge and skills during INSET training to help teachers improve quality of teaching mathematics in secondary schools.

\section{REFERENCES}

[1] Abe, O.T. (2014). The effect of teachers' qualification on students' performance in mathematics. Retrieved on $16^{\text {th }}$ June 2018 from http://wwwsky journals.org/STER. Sky. Journal of Education. Research Vol.2(1),pp 010-014.

[2] Adaramola, M.O. \& Obumanu, B.J. (2011). Factors related to under achievement in Science, Technology and Math Education (STME) in Secondary Schools in River state, Nigeria, World Journal of Education 1(1), 102-109.

[3] Abu, P.B., and Fabunni, M. (2005). The relationship between teacher variables and adult learners academic performance. International Journal of African American studies, 4(1), 12-20.

[4] Akinsolu, A.O.(2010).Teachers and students Academic Performance in Nigerian Secondary schools: Implication for planning Florida Journal of Educational Administration \& Policy Vol.3,(2), pp 86-103.

[5] Akpo, S.E.(2012). The impact of teacher related variables on students' academic performance in public secondary schools in Delta state, Nigeria. Stud Homm Comm Sci, 3(2),107 -113.

[6] Ankomah, Y.,Koomson, J.,Odun, G.K. (2005). Implementing quality education in low income countries. Institute for Education, Planning and Administration(IEPA0. University of Cape Coast, Ghana.

[7] Armstrong, C.,De Beer, J., Kawooya, D., Prabhola, A., \& Schonwetter, C.(2010). Access to Knowledge in Africa. Retrieved on $20^{\text {th }}$ September, 2018 from http://www.witsac.ka

[8] Asikhia, O.A. (2010). Students' and Teachers' perception of the causes of poor academic performance of secondary schools in Ogun state. European Journal of Social Sciences vol.13(2),229 - 242.

[9] Darling-Hammond, L., Berry, B., \& Thorenson, A. (2001). Does teacher certification matter? Evaluating the evidence. Educational Evaluation and Policy Analysis, 23(1)57-77.
[10] Darling-Hammond, L. (2000). Teacher quality and students achievement: A review of state quality evidence. Education PolicyAchieves 8(1), 1-44.

[11] Daso, P.A. (2013). Teacher variables and senior secondary students achievement in mathematics in River state, Nigeria. European Scientific Journal, 9(10), 271-289.

[12] Dodeen, H., Saleh, A. Faisal., \& Hilal, M.A. (2012). The Effects of Teacher Qualifications, Practices and Perception on students Achievement in TIMSS Mathematics: A Comparison of Two Countries. International Journal of Testing. Vol.12, pp. 61-72. Retrieved on January $10^{\text {th }} 2019$ from http://www. esearchgates.net/Publication/239794812.

[13] Federal Government of Nigeria.(2010). National policy on Education: Revised. Lagos: NERDC Press.

[14] Goldhaber, D. D. \& Brewer, D. J. (2000). Does teacher certification matter? High school teacher certification status and student achievement. Education Evaluation and Policy Analysis Vol.22 (1),29-45.

[15] Greenburg, E., Rhodes, D., Ye, X., \& Stancavage, F. (2004). Prepared to teach: Teacher preparation and students achievement in Eighth grade Mathematics. American education research association, 2004 annual meeting, San Diego.

[16] Hanushek, E. (2000). The impact of differential expenditure on school performance. Educational Research Vol. 14, (4), pp. 20- 25.

[17] Indumuli, J., Mushira, N., Kuria, P., Ndung'u, R., \& Waichanguru, S (2009). Teaching primary mathematics. Nairobi, Enterprise Road Jomo Kenyatta Foundation.

[18] Ingvarson, L.; Beavis, A.; Bishop, A.; Peck, R., \& Elsworth, G. (2004). Investigation of Effective Mathematics teaching and Learning in Australian Secondary Schools. Australia: Australian Council for Educational Research.

[19] Jaime, C.D. (2008). The effect of Teachers' experience and teachers degree levels on students achievement in mathematics and Communication Arts.

[20] Kimani, G. N., Kara, A.M. \& Njagi, L. W. (2013). Teacher factor influencing students'Academic Achievement in Secondary schools in Nyandarua County, Kenya. International Journal of Educational Research 1(3), 1-4.

[21] Kosgei, A. (2013). Influence of teachers background on student academic achievement among secondary schools. Moi University, Eldoret: Kenya.

[22] Kothari, C. R. (2004). Reseach methodology. Methods and Techniques. New Delhi: Wishwa Prakashan.

[23] Krathwohl, D.R.(2003).Educational and Social Science Research an Integrated Approach. Toronto: Longman.

[24] Maguswi, B. (2021). Factors contributing to under achievement of Zambian female students in 0-level Physics examination. A vase of selected high schools in central Province. Master Thesis University of Zambia.

[25] Mugenda, O.M. \& Mugenda, A.G. (2003). Research Methods: Quantitative and Qualitative Approaches. Nairobi: ACTS Press.

[26] Masau, L.M.\& Migosi, J.A.(2015). Teacher qualification and students academic performance in Science, Mathematics and Technology subjects in Kenya. International Journal of Education Administration and policy studies, Vol 7(3)pp 83-89. Retrieved on $20^{\text {th }}$ July2018 from http://www.acdemiajournals.org/IJEAPS.

[27] Oduh, W.A. \& Okanigbuan, P.N.(2014). Relationship between Teachers' Qualification and students' performance in mathematics among students of private secondary schools in Ikpoba-Okha Local Government Area of Edo state, Nigeria. Journal of Emerging Trends in Educational Research and Policy Studies (JETERAPS), 5(4) pp 
416-422 scholarlink Research Institute journals 2014(ISSN:2141-6990)

[28] Olalaye, F.O. (2011). Teachers characteristic As predictors of Academic Performance of Students in secondary schools in Osun State, Nigeria. European Journal of Educational Stud 3(3), 505-511.

[29] Umar, A.A., Yashe, A. \& Awogbemi, C. A.(2013). Effects of Teachers' Qualification on Performance in Further Mathematics among Secondary School Students. Mathematics Theory and Modelling: ISSN 2224-5804, Vol.3 No.11.Retrieved on $20^{\text {th }}$ June 2018 from www.iiste.org.

[30] UNESCO (2009). Policy guidelines on inclusion in Education.

[31] University of Nairobi (2007). Rating Scale for Undergraduate Courses.

[32] Villegas-Reimers, E.(2003).Teacher professional development: an international re-view of the literature. Paris; International institute for Educational Planning.

[33] Walshaw, M.,\&Antony,G.(2008). Characteristics of effective pedagogy for mathematics education. In Forgasz, H., Barkatsas,T., Bishop, A., Clarke, B., Sullivan

[34] Wenglinsky, H. (2000). How teaching matters: Princeton, NJ; Educational testing service. 